\title{
Protection of children by substitute consent: A universal principle and right
}

\author{
R Rheeder, BA, ThB, ThM, ThD \\ Unit for the Development of Reformed Theology, North-West University, Potchefstroom, South Africa
}

\begin{abstract}
Corresponding author: R Rheeder (riaan.rheeder@nwu.ac.za)
\end{abstract}
\begin{abstract}
In 2005, the world community and the United Nations Educational, Scientific and Cultural Organization (UNESCO), comprising 191 member nations, unanimously accepted the Universal Declaration on Bioethics and Human Rights (UDBHR). This declaration is the first and only bioethical text to which the entire world has committed itself and helps put bioethics on the agenda of states. However, it appears to have had little or no impact in South Africa (SA). This article aims to join UNESCO's mission and to form part of the social responsibility initiative of teaching the universal right and the ethical principle of proxy consent in the context of medical intervention to promote the UDBHR in SA. We compare the UDBHR and SA Children's Act No. 38 of 2005. It is clear that the world community sees surrogate consent as the right and duty of all communities.
\end{abstract}

S Afr J BL 2015;8(2):41-43. DOI: 10.7196/SAJBL.441

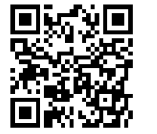

This study discusses Article 7 of the Universal Declaration on Bioethics and Human Rights (UDBHR) by the United Nations Educational, Scientific and Cultural Organization (UNESCO), which UNESCO has decalred a universal right and an ethical principle: ${ }^{[1]}$ 'In accordance with domestic law, special protection is to be given to persons who do not have the capacity to consent: (a) authorization for research and medical practice should be obtained in accordance with the best interest of the person concerned and in accordance with domestic law. However, the person concerned should be involved to the greatest extent possible in the decisionmaking process of consent, as well as that of withdrawing consent.'

The medical world generally accepts that paternalism has been replaced by the principle of informed consent. Before medical intervention, the person must receive the necessary information and grant permission for intervention. In reality, some people are unable to understand the medical information and are unable to grant permission before medical intervention, although they have medical needs. To solve this problem, UNESCO developed Article 7a, stating that substitute consent with a view to medical intervention is permissible as a universal right. ${ }^{[2]}$

The UDBHR forms a kind of common morality, which means that the principles are shared or accepted by almost all the countries in the world. The UDBHR was accepted unanimously by the world community (191 member countries) in $2005{ }^{[3]}$ This declaration is the first and only political and bioethical text to which all the governments in the world, including South Africa (SA) ${ }_{1}^{[4]}$ have committed themselves. However, Langlois, ${ }^{[5]}$ who studied in depth the reception of the UDBHR in Kenya and SA, states, ${ }^{\prime} .$. The Universal Declaration helps put bioethics on the agenda of States. ... It appears to have had little or no impact in SA, however, on what is a growing and developing bioethics community. Meagre input into the drafting of the UNESCO declarations by the scientists and ethicists who must apply ethical principles in their everyday work, together with the lack of an in-country champion (a UNESCO chair or IGBC member, for instance), may have hampered take-up.'

This situation could and should be addressed by bioethics education through scientific writings. Referring to Article 23 of the UDBHR, Berlinguer declares that education in (universal) bioethics must be promoted by governments and that all scientific institutions must contribute to education which should also take place in an interdisciplinary way ${ }^{[6]}$ Two UDBHR researchers from Africa are convinced that bioethics education is necessary in Africa: 'The relevance of bioethics education in Africa is not in doubt ... Despite the efforts by UNESCO to promote bioethics education in Africa, it is still in its infancy and its development is bedeviled by numerous challenges.![]

Unlike the other bioethical instruments, the UDBHR is directly aimed at developing countries: ${ }^{[1]}$ 'to promote equitable access to medical, scientific and technological developments as well as the greatest possible flow and the rapid sharing of knowledge concerning those developments and the sharing of benefits, with particular attention to the needs of developing countries. The International Bioethics Committee (IBC) study on Articles 6 and 7 was also done with a pedagogical aim in mind. ${ }^{[3]}$ This article aims to join UNESCO's mission and to form part of the social responsibility initiative of teaching the universal right and ethical principle of proxy consent to promote the UDBHR in SA. In this regard: 'First, it is important to make sure that scientists, healthcare professionals, and policy-makers all over the world are informed about the existence and the contents of the Declaration. ${ }^{[8]}$ Secondly, the following comment has been made regarding the relationship between bioethics and legislation in Africa: ${ }^{[7]}$ 'The bioethical practices and reflections are not guided by any known legislation, but by controls within the wide spectrum of communities. Communities have their own rules and regulations when dealing with bioethical practices and they slavishly adhere to them. However, with the high diversity of communities, African bioethics lacks universality and this makes the application of legislation very complicated.'

Are the allegations true that bioethical practices in Africa and, by implication, SA, are not governed by legislation and that in Africa and SA, bioethics lacks universality? These claims are evaluated by means of the question: Are children protected in SA regarding medical intervention and if so, does the protection agree with universal guidelines. The relevance of this evaluation is found in the following comment: ${ }^{[9]}$ ' $A$ major concern was that international medical research and healthcare endeavours would proceed along double standards so that people in developing countries would receive substandard care and be involved in clinical trials without the ethical protection that exists in developed countries.' 
To meet these objectives we compare the UDBHR and Children's Act No. 38 of 2005. In developing the UDBHR's Article 7, a distinction was made between consent with medical practice (Art. 7a) and research (Art. 7b). ${ }^{[3,10]}$ We consider only consent with medical intervention in view; a distinction also made by UNESCO ${ }^{[11]}$ Children in SA are protected by the Children's Act No. 38 of 2005, specifically within the context of medical intervention (medical treatment and surgical procedures). ${ }^{[12]}$ This paper concentrates on the UNESCO publications that explain and interpret the international promotion and education of the UDBHR. ${ }^{[13]}$

\section{Substitute consent as universal value Surrogate consent}

The content of Article 7a that deals with special protection of persons who do not have the capacity to give their consent, is considered:

- First, the concept of incapacity, which forms the reason for protection

- Second, human dignity, which serves as motivation for protection

- Third, substitute consent as manner of protection.

Incapacity is indicated as the reason for the need for special protection as there are individuals who do not have the capacity or ability to take autonomous decisions, ${ }^{[3]}$ although they need healthcare. ${ }^{[10]}$ What is understood by 'incapacity' or the 'inability' to take personal decisions regarding medical intervention? The Bioethics Core Curriculum defines 'incapacity' as: 'Incapacity can be defined as lacking the freedom to make authentic decisions because of an inability to make such decisions even when given the opportunity. ${ }^{[11]}$ This definition indicates people who cannot act in their own best interests and includes groups such as newborn infants and minors, clinically confused people, persons with learning difficulties, mentally handicapped people and unconscious people. ${ }^{[10]} \mathrm{A}$ distinction is also made between no and limited capacity and in the latter, a variable degree of capacity. ${ }^{[2,3]}$

Secondly, human dignity provides the motivation for special protection and is the point of departure in Article 3 of the UDBHR. There is a causal connection between Articles 3 and 7 of the UDBHR in the way that human dignity forms the rationale for persons without capacity having a right to be protected within the medical environment. ${ }^{[3,10,14]}$ This is confirmed by Article 2 of the UDBHR, which states that the aim of the declaration is, among others, 'to provide a universal framework of principles' with the specific goal 'to promote respect for human dignity.[1] Article 7 supports the human dignity of persons without capacity ('persons who do not have the capacity to consent') and their right to be treated with human dignity.

Thirdly, substitute consent, as a method of protection, is accepted by the world community. Under 'protection' is understood that 'authorization for ... medical practice should be obtained.'[10,15] This authorisation is understood as substitute consent, ${ }^{[3]}$ which means that another person or body may grant permission for medical intervention on behalf of the person involved. The implication of this principle is that the right to grant permission is transferred to another person or institution; e.g. where parents may take decisions on behalf of their children. UNESCO and the global community acknowledge that something in the nature of loving substitute consent exists: 'Some benevolent paternalism takes place in real life and, in our opinion, is not necessarily misguided or exerted against the patient's wishes. It is a matter of finding honestly the right balance considering a trusting human relationship, the wish to support and protect a comparatively fragile individual, and the ethical and legal rules.[10]

\section{Directives for consent}

There is global bioethical consensus that consent should not rest upon the exclusive autonomy of the surrogate, but should be authentic (autonomy as authenticity). ${ }^{[2]}$ According to the UDBHR, it means that substitute decisions must meet the following three criteria for consent to be authentic: $:^{[2,3]}$

\section{Best interests}

The surrogate may only grant consent that will further the best interests of the person ('in accordance with the best interest of the person concerned'). This first criterion mentioned in Article 7a, means that all consent must be led by this criterion, but that it is especially appropriate when a person is permanently without capacity to grant permission for intervention. What do UNESCO and the world community regard as the best interests? Article 3 of the UDBHR determines that 'the interests and welfare of the individual should have priority over the sole interest of science or society. ${ }^{[1]}$ This principle aims to protect the person against harm where an individual could be exploited by the community as a means to an end. ${ }^{[2]}$ Article 4 of the UDBHR refers directly to best interests as: ${ }^{[1]}$ 'In applying and advancing scientific knowledge, medical practice and associated technologies, direct and indirect benefits to patients, research participants and other affected individuals should be maximized and any possible harm to such individuals should be minimized.'

In Bioethics Curriculum Section 1: Syllabus Ethics Education Programme, an official handbook and commentary of the UDBHR, UNESCO describes best interests as the following: $:^{[1]}$

- Protection and defence of a person's rights (the right to health)

- Prevention of harm in the form of illness and impairment to a person (preventive action)

- Alleviation or diminution of harm to a person (palliation of the effects of disease; relief of pain)

- Elimination of circumstances that would cause harm to a person (healing)

- Helping people with disabilities

- Psychological help

- Saving people from risk

- Balancing of benefits, disadvantages and cost regarding the person.

Linking with these, best interests is also regarded as the absence of the following harming actions: ${ }^{[10]}$

- Physical harm (killing or the causing of pain and suffering)

- Psychological harm (offence and unkindness)

- Moral harm (having no regard for the ethical interests of the individual)

- Social and economic harm (stigmatising or exploitation)

- Spiritual harm (religious discrimination)

- Adequate information.

Article 6 of the UDBHR states that in order to grant consent for medical intervention that will be in the best interests of the patient, the surrogate must receive the same information as a person with capacity would have received before making a decision. ${ }^{[2]}$ Article 6 of the UDBHR declares that informed consent must comprise adequate information. ${ }^{[1]}$

The UDBHR also states that substitute consent must be granted in accordance with domestic law ('authorization for ... medical practice should be obtained ... in accordance with domestic law').

\section{Participation}

The person without capacity must be involved in the decision-making process as far as possible. Regarding the principle of participatory 
decision-making; 'the person concerned should be involved to the greatest extent possible in the decision-making process of consent'. Ethical responsibility is the following: 'One can say that the generally accepted ethical position considers that the physician ... is not exempted, for example, to try as best as he can to inform children, handicapped persons or mental patients in order to obtain from them the best possible consent ... that is to take maximum advantage of the person's potential contribution to the decision to be made, be it to consent or to refuse. ${ }^{\text {[10] }}$

Article 5 of the UDBHR states that participatory consent is aimed at people with (gradual) limited incapacity and that the principle of autonomy should be respected as far as possible, therefore the directive that children should not be excluded or alienated from the decision-making process as a matter of course. ${ }^{[10]}$ This norm aims to protect a person without capacity against absolute paternalism and where persons are totally deprived of their basic right or juridical capacity to grant consent and to place the decision-making completely in the hands of a parent or guardian. ${ }^{[2]}$ This directive requires that the opinion of children be taken into account proportionally to their age and capability, ${ }_{1}^{[2]}$ and should not be linked exclusively to a certain age. Together with participating consent, the UDBHR also states the principle of withdrawal of consent..$^{[3]}$ In this case participatory consent must be considered as a form of best interest that does not exclude the comprehensive notion of best interest mentioned above.

\section{Assessment}

UNESCO accepts in its declaration that by virtue of human dignity, children must be considered as persons without capacity who must be protected by means of substitute consent during medical intervention. These universal ethical guidelines are underwritten by the Children's Act No. 38 of 2005:

- Chapter 7: Protection of Children Part 3: Protective measures relating to health of children 129 . Consent to medical treatment and surgical operation.

- All proceedings, actions or decisions in a matter concerning a child must- ... b) respect the child's inherent dignity...

- ... a child may be subjected to medical treatment or a surgical operation only if consent for such treatment or operation has been given in terms of either subsection... ${ }^{[12,16]}$

The UDBHR indicates directives that must be considered when parents or guardians give substitute consent within the context of medical intervention, namely: best interests; receiving relevant information; in accordance with domestic legislation; and participatory decision-making. These universal ethical guidelines are expressed in the Children's Act No. 38 of 2005 and must be considered in the decision-making process:

- In all matters concerning the care, protection and well-being of a child the standard that the child's best interests is of paramount importance, must be applied.

- Every child has the right to have access to information on health promotion and the prevention and treatment of ill-health and disease, sexuality and reproduction.

- Every child that is of such an age, maturity and stage of development as to be able to participate in any matter concerning that child has the right to participate in an appropriate way and views expressed by the child must be given due consideration. ${ }^{[12,17]}$

We can conclude that there is a remarkable similarity between the global bioethical guidelines of the UDBHR and the Children's Act No. 38 of 2005.

\section{Conclusion}

The world community sees surrogate consent as the right and duty of all communities and is convinced that, based on human dignity, people without capacity and specifically children, must be protected within the medical environment by substitute consent. This consent is not left to the autonomy of the surrogate, which means that all consent must be directed by the norms of best interests and participatory decision-making. Comparing the UDBHR with the Children's Act No. 38 of 2005, we conclude that the Children's Act concurs with universal bioethical guidelines and ideals of human rights regarding the protection of children during medical intervention. Therefore, the allegation ${ }^{[7]}$ that African and South African bioethics is not universal in nature is incorrect in the case of domestic legislation's medical protection of children. Bioethical discussion without reference to UDBHR in SA is incomplete. We trust that this discussion contributes to a greater awareness of it.

\section{References}

1. UNESCO. Universal Declaration on Bioethics and Human Rights. Paris: UNESCO Publishing, 2006. http://unesdoc.unesco.org/images/0014/001461/146180e.pdf (accessed 18 November 2013).

2. Gefenas E, Tuzaite E. Persons without the capacity to consent. In: Ten Have H, Gordijn B, eds. Handbook of Global Bioethics. Dordrecht: Springer Science and Business Media, 2014:85-103.

3. International Bioethics Committee. Report of the International Bioethics Committee of UNESCO (IBC) on Consent. France, IBC, 2008. http://unesdoc. unesco.org/images/0017/001781/178124e.pdf (accessed 18 November 2013).

4. UNESCO. Records of the General Conference 33rd session Paris, 3-21 October 2005, Volume 1 Resolutions. Paris: UNESCO Publishing, 2005. http://unesdoc unesco.org/images/0014/001428/142825e.pdf (accessed 18 November 2013).

5. Langlois A. Negotiating Bioethics: The Governance of UNESCO's Bioethics Programme. New York: Routledge, 2013.

6. Berlinguer G. Article 23: Bioethics education, training and information. In: Ten

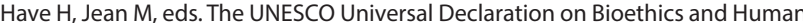
Rights: Background, principles and application, Ethics series. Paris: UNESCO Publishing, 2009:309-315.

7. Mathooko J, Kipkemboi J. African perspectives. In: Ten Have H, Gordijn B, eds. Handbook of Global Bioethics. Dordrecht: Springer Science and Business Media, 2014:253-268.

8. Ten Have H, Gordijn B. Structure of the compendium. In: Ten Have H, Gordijn B, eds. Handbook of Global Bioethics. Dordrecht: Springer Science and Business Media, 2014:35-41.

9. Ten Have H, Gordijn B. Global bioethics. In: Ten Have H, Gordijn B, eds. Handbook of Global Bioethics. Dordrecht: Springer Science and Business Media, 2014:3-18.

10. Martin JF. Article 7: Persons without the capacity to consent. In: Ten Have, H, Jean M, eds. The UNESCO Universal Declaration on Bioethics and Human Rights: Background, Principles and Application, Ethics series. Paris: UNESCO Publishing, 2009:139-154.

11. UNESCO. Bioethics Core Curriculum. Section 1: Syllabus Ethics Education Programme Sector For Social And Human Sciences Division Of Ethics Of Science And Technology. Paris: UNESCO, 2008. http://unesdoc.unesco.org/ images/0016/001636/163613e.pdf (accessed 18 November 2013).

12. Snead OC, Mulder-Westrate K. Autonomy and individual responsibility. In Ten Have H, Gordijn B, eds. Handbook of Global Bioethics. Dordrecht: Springer Science and Business Media, 2014:75-83.

13. UNESCO. Explanatory Memorandum on the Elaboration of The Preliminary Draft Declaration on Universal Norms on Bioethics. Paris: UNESCO Publishing, 2005. http://unesdoc.unesco.org/images/0013/001390/139024e.pdf (accessed 7 October 2014).

14. Pellegrino ED. Article 4: Benefit and harm. In:Ten Have, $H$, Jean $M$, eds. The UNESCO Universal Declaration on Bioethics and Human Rights: background, principles and application, Ethics series. Paris: UNESCO Publishing, 2009:99-110.

15. UNESCO. Casebook on Bioethics and the Holocaust. Paris: UNESCO Publishing, 2013. http://www.unesco-chair-bioethics.org/UI/F0101.aspx?uid=F8D02FF3F880A4FE (accessed 18 November 2013)

16. Republic of South Africa. Children's Act 38 of 2005, Section 129(1); Section 2 (a)(b); Part 3, Protective measures relating to health of children (ss 129 - 142); Section 129(1); Section 129, Consent to medical treatment and surgical operation. Pretoria: Government Printer, 2005.

17. Republic of South Africa. Children's Act 38 of 2005, Section 9; Section 13(1)(c); Section 7; Section 129(2)(3); Section 10,31(1). Pretoria: Government Printer, 2005. 